Article

\title{
Religious Commitment, Subjective Income, and Satisfaction towards the Functioning of Democracy in Latin America. A Mediation Analysis Model Based on Latinobarómetro
}

\author{
Daniel Barredo Ibáñez
}

School of Human Sciences, Universidad del Rosario, Bogotá, Colombia; daniel.barredo@urosario.edu.co

Received: 30 April 2018; Accepted: 15 June 2018; Published: 20 June 2018

\begin{abstract}
Religion and politics in Latin America maintain a close relation that, along with a historical background in European colonization, remains in force through both being institutionalized in some political parties or ideologies, and diluted in the societies that make up this region. This paper examines the relation between three variables: religious commitment, subjective income, and satisfaction toward the functioning of Latin American democracies. To do so, we have constructed a hypothetical model based on a mediation analysis of 20,204 surveys that were collected by Latinobarómetro in 2016. The results confirm the existence of an indirect positive effect that is motivated by religious commitment, and mediates between perceived income and being satisfied with democracy in Latin America. In other words, as the respondents recognize that they have a greater subjective income and a greater religious commitment, they will probably manifest greater satisfaction toward the functioning of democracy. Such behavior highlights the referential nature of the religious experience by contributing to the emotional reinforcement of the social context perceived by Latin Americans.
\end{abstract}

Keywords: religious commitment; Latin America; democracy; Latinobarómetro

\section{Introduction}

Throughout the globe, to a greater or lesser extent, we can find a close association between religion and politics (Levine 1981); this association is likely all the more so, if possible, in Latin America, where, as explained by the cited author, both spheres have been responsible for mutually reinforcing their legitimacy and social prestige. In this context, there is a multiplicity of religious beliefs, and although Catholicism is the dominant tendency, there is a continuous decrease in the number of believers. If it is true that during most of the 20th century, and in most of the countries of the region, about nine out of 10 people were Catholic, since the 1960s, this number has decreased to an average of seven out of 10 individuals (Pew Research Center 2014, November 13). According to this study, evangelicals have been registering an upward movement: 9\% of Latin Americans grew up under the influence of Protestant worship centers, and at the time of the survey, 19\% admitted to being part of evangelicalism (Pew Research Center 2014, November 13).

In that regard, Mallimaci (2017) describes the loss of the monopoly of the previous centuries that the Catholic Church has suffered due to new tendencies that have gained strength, such as the Pentecostal churches, to which seven out of 10 Protestants in Latin America belong (Pew Research Center 2014, November 13). Many authors (Jungblut 2015; Cipriani 2015; Parker 2016; Zavala and Góngora 2016; Blancarte 2016; Sarrazin and Arango 2017) agree with the issue of losing believers, or rather, the transfer of parishioners to other religions. This process is fundamentally due to the following differentiating elements of evangelicalism: "the relationship with the divine, the forms 
of worship, the ethical dimension, collective solidarity and concern for people" (Cipriani 2015, p. 272), along with a more personalized and at the same time collective treatment, in opposition to a greater indifference between the Catholic Church and its believers (Sarrazin and Arango 2017). So, if we add the numbers of evangelicals and Catholics from the Pew Research Center (2014, November 13), we find that about nine out of 10 Latin Americans belong to a religion, just as the previous century, but those were only Catholics then. Although the number of evangelical believers is increasing, there is still an unequal relation with Catholic believers (Levine 2015), as the Catholic Church has a greater involvement and participation in the political life of the region, while the evangelical organizations-as the author indicates-are gradually penetrating the spheres of power as their number of believers also increases. This inequality is based, above all, on tradition and on historical relationships anchored in preferential agreements and treaties that have made the Catholic Church be considered the "dominant religion" (González and Sánchez 2006, p. 124), and therefore, enabled its precepts to receive institutionally privileged treatment.

Behind the progressive decline of Catholics, the dual and controversial role that-as explained by De la Torre and Martín (2016) —Catholicism has had in Latin America is worth highlighting. On the one hand, it has served as a symbolic instrument at the service of the domination and the cultural subjection of native diversity; on the other, it has been an ally to foster greater recognition of the problems associated with workers and some indigenous sectors. The Catholic Church has also been a powerful instrument for the annulment of the pre-Hispanic religious and cultural difference (Mato 2015). Since European colonization, Catholicism sank its roots into politics, and vice versa, so much so that the kings of Spain and Portugal, along with ruling, would also be in charge of guarding the values associated with this religion (De Roux 2014). This would happen to the point that with the "Republicanization" of Latin American countries-and their corresponding independence from the monarchical state headquarters-the Roman Curia "undertook the slow task of regaining control" (p. 33). In fact, in the very processes of independence, we find an active involvement of the Church, both in elite accomplices to ensure the maintenance of the Crown in the nascent republican territories, as well as priests who, on occasion, collaborated with the emerging political leaders and their respective ideals. Not surprisingly, let us remember that, to cite an example, the first printing press that was introduced in Colombia was ordered by the Jesuit congregation (Ortega and Chaparro 2012). This innovation would change the future of the country by promoting the dissemination of republican values and the demystification of the King of Spain, who was until then considered immovable (Barredo 2017).

Overall, the Catholic Church has been essential in this part of the world, such as for example in stimulating the emergence of charismatic and populist leaderships, which are a reflection of the political and cultural past attached to the social imaginary (Zanatta 2008). According to this author, the intersection between religion and politics in Latin American populism is perceived in the Manichaeism, the idealized vision of a primitive community, and the establishment of an inspired hierarchy ruled by the divine order as well as in the invocation of a "religious cosmology" (p. 41). Therefore, Manichaeism, as a tendency that reduces and polarizes reality in terms of good and bad, has strong cultural roots associated with the historical development of Latin America. Let us recall that, as described by Quijano (2011), the colonizers imposed categories that fostered the grouping of ethnic and religious heterogeneities (natives, blacks, Spaniards, to name the most relevant). That is why populist leaders-who, even as seculars, embody the messianic role as envoys of chance or of the heavens-try to establish frequent dichotomies between rich and poor, revolutionaries and conservatives, among others. However, for Laclau (2006), populism arises after the dichotomous partition of the public sphere; that is, through a process of the degradation of institutions and the emergence of a leader who is capable of channeling the discontent of the masses.

On the other hand, during much of the 20th century, we find in the Latin American government systems what Lipset (1959) described as "unstable democracies and dictatorships" as well as "stable dictatorships" (p. 74); according to this classic work, not a single Latin American country was 
considered a stable democracy. Within that climate of general instability, there was a strong link between dictatorships and various religions, especially with Catholicism, as Mallimaci (2017) explained. However, the role of religious organizations is controversial, in that they have also been allies of the search for dialogued solutions to dictatorial or highly conflictive systems, as in the cases of Chile or Peru, among others (Levine 2015). Decades later, only an authoritarian regime persists in the region-Cuba (Mainwaring and Pérez-Liñán 2015)—and although the democratic model has been generalized in all of the countries of the region, these same authors warn of great general instability, as well as the systemic erosion or stagnation, based on examples such as Venezuela, Nicaragua, or Mexico, to name the most relevant. However, Latin American democracies have been advancing in terms of strengthening institutionality or transparency (De la Torre 2005), although there are still worrying and dissatisfying figures regarding the representative institutions in these countries (Monsiváis 2017).

The following pages have been constructed to examine what the interaction between religious commitment, subjective income, and satisfaction toward the functioning of democracy is in this region of the world. As it will be presented, the analysis tries to build up a diagnosis of the related interaction after reviewing the data related to individuals of the 18 Latin American countries surveyed by the Latinobarómetro in 2016. Despite its possible limitations facing a really diverse complex region identified by common languages and cultures, this study aims to contribute to the study of religion and politics in Latin America, which is a relation that is still largely understudied (Iranzo and Manrique 2015).

\subsection{Education, Religious Commitment, and Support toward Democracy}

Education is fundamental for the support of a democracy (Lipset 1959), since individuals with higher levels of education tend to adopt a greater tolerance toward the points of view of others. Education also affects the religious commitment, which can be described, according to Koenig et al. (2015), as a form of "religious involvement" (p. 66). These researchers include in this factor a series of variables, such as for example "religious attendance", "religious volunteering", and "conform to religious teachings" (p. 72), among others. In the configuration of the religious commitment, cultural context and personal education are determinant (Koole et al. 2010), but according to the quoted authors, there are some essential values in the religions that tend to identify the practices and the beliefs of the different human groups.

In the Latin American case, the region is divided between countries with a strong Catholic Church presence and, at the same time, others where said presence has been secularized (De la Torre and Martín 2016). However, in general, if Latin American elites tend to form around centers associated with the Catholic religion (De Roux 2014), it is also true that this institution tends to be responsible for the training of individuals from the farthest regions. Latin America is one of the regions with the highest number of elementary and high school students enrolled in private centers in the world (Verger et al. 2017), but authors such as Mato (2015) also point out the persistence of values associated with Catholicism in the curricula of the region; therefore, Latin Americans tend to be taught under the Catholic imaginary, instead of under views associated, for example, with other religions or pre-Hispanic native cultures, which are often displaced by stereotyped and prejudiced approaches.

Since the end of the 19th century, the Catholic Church was rethinking its level of relation with the Latin American states when two ideologies appeared: that of "social Catholicism" and also that of "integral Catholicism" (De Roux 2014, p. 45). The first of them was very active politically and fostered a link with some social sectors-such as the working class-and an institutional link with the political doctrines of the time, which was made visible in the emergence of Christian democratic political organizations. On the other hand, the second rejected its association with political doctrines, and instituted a more inflexible profile that sought the fusion of the private and the public sphere. However, in the last decades of the 20th century, the Catholic Church was facing the rapid growth of Protestantism in the region, which is causing the decline of the aforementioned Catholic believers. For Jungblut (2015), one of the keys that explained the increase of evangelicals is the association of 
these liturgies with some modern phenomena, such as the "rhythms and styles of profane musicality" (p. 107), or even its connection with contemporary shows such as soccer, which to a certain extent were omitted from Catholic practices. Likewise, a greater horizontality in evangelical relations is also perceived, along with a greater empathy toward individual emotions (Sarrazin and Arango 2017), which is somewhat distinctive with respect to the greater verticality and indifference that is practiced, according to these authors, by the Catholic Church.

Whether Catholic or evangelical, in any case, religion exercises a strong symbolic power in the processes of emancipation and mobilization of the region (Levine 2015; Mallimaci 2017). In countries such as Venezuela, Costa Rica, Nicaragua, El Salvador, and Guatemala, among others, we find political parties associated with Christian democracy (Parker 2016), without counting on the fusion that, as this author explains, took place between ideologies such as socialism and Christian values. However, the interrelation between religion and politics can also be encouraged from other areas, such as liturgy. Thus, in a study on the relation between politics and religion in the United States, it was concluded that two-thirds of the faithful had heard the preaching of a priest on a hot topic-such as discussions on homosexuality or the problems of abortion, among others-when worshipping (Pew Research Center 2016, August 8). This way, churches can create a space of reflection that is not only on the sacred themes linked to the cult, but also on those other controversial issues that make up the public agenda. According to the same work cited, the discussion is instrumentalized as a form of indoctrination. For example, $22 \%$ of adult Americans surveyed on abortion claimed that priests had launched diatribes against abortion, but only $3 \%$ admitted to having attended a clerical parliament in favor of it; with regard to immigration, $19 \%$ said that priests expressed positive encouragement in their homilies for supporting and welcoming immigrants, but only $4 \%$ stressed that it was important to reinforce border control.

Paradoxically, although there is religious freedom in many of the Latin American states, the Catholic Church has a preponderant recognition, even from the individual constitutions of the different countries (González and Sánchez 2006). Blancarte (2016) has also perceived contradictions between the state apparatus, the normative set, and individuals. In this regard, this author says that there are countries where the church-especially the Catholic Church-maintains a strong link with the state and, nevertheless, society manifests a great liberalism and secularization. However, in other cases, there are also states with a narrow laicizing stimulus that is not reciprocated in societies where the unwritten values of religion are preserved.

\subsection{Subjective Income and Satisfaction toward Democracy}

Democracy, as Lipset (1959) already explained, requires certain conditions to ensure its stability. Among them, according to this author, includes highlighting "economic development and legitimacy" (p. 71). However, in spite of the widespread corruption cases, together with economic instability and politicians and institutions' loss of credibility between 1996-2009, support and the satisfaction toward democracy have been stable (Wences and Güemes 2016). However, subjective income, which refers to the level of agreement of individuals with salaries in a country, stands as an indispensable variable for understanding support for a democratic system. Thus, according to De la Torre (2005), a majority of Latin American citizens would be receptive to replacing the system for the sake of a higher payment, which is usually associated with a better quality of life. Likewise, studies such as that of Alister et al. (2015) indicate the existing link in Latin America between "satisfaction with democracy" and "personal economic situation" (p. 102). These authors also link other variables, such as "government performance" (p. 104), which collects the perceptions of the citizens surveyed on the initiatives deployed by the current constituents. Other variables include the "economic situation of the country", including the internal or external efficiencies, as well as "trust in the president" or in other individuals (p. 107). On the other hand, Wences and Güemes (2016) suggest that in order to encourage greater satisfaction toward the functioning of democracy, it is important to reinforce levels of trust, and in particular, of "social trust, singular trust, and institutional trust" (pp. 16-17). 
According to these authors, the first type is linked to interpersonal trust and between the individual and the groups that structure society; the second, in particular, refers to the trust that revolves around the family and friend nucleus; and, finally, the third refers to the trust that the individual maintains with the institutions. In a similar way, Ergun et al. (2016) assures that satisfaction toward democracy is closely correlated with electoral management; this way, and according to these authors, it will be more likely to find greater satisfaction in those countries that have greater transparency and quality in the electoral processes. In Latin America, this does not seem to be happening: more than half of Latin Americans are dissatisfied with the institutions that represent them (Monsiváis 2017). In general, according to Zmerli and Castillo (2015), income inequality is responsible for some of the structural problems in societies, such as for example "social distrust, less solidarity, corruption, bad governance, or weakening political support" (pp. 179-80). So, following these authors, it is possible to understand that there is a link between subjective income and satisfaction with the functioning of democracy.

\section{Hypothesis}

These pages have been written based on the following hypotheses:

H1: Subjective income (X) positively influences satisfaction toward the functioning of democracy $(Y)$.

H2: Subjective income $(X)$ positively influences satisfaction toward the functioning of democracy $(Y)$ through religious commitment ( $M)$.

H2.1: Subjective income $(X)$ positively influences religious commitment $(M)$.

H2.2: Religious commitment $(M)$ positively influences satisfaction toward the functioning of democracy $(Y)$.

In order to graphically explain the hypotheses proposed in Figure 1, we have drawn up a multivariate model that is responsible for describing the relations to be studied:

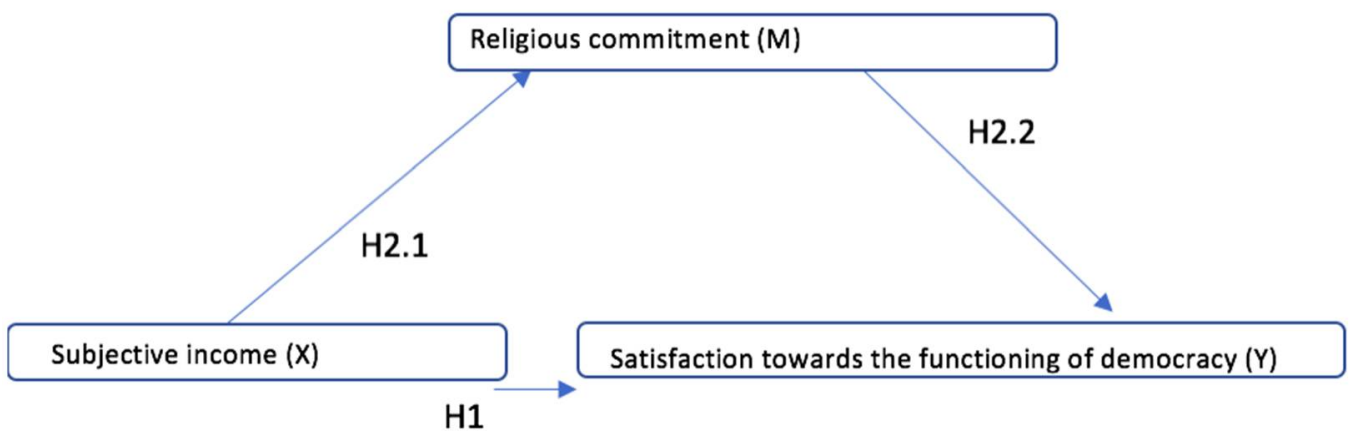

Figure 1. Hypothetical model proposed by the study.

In this work, we examine the relation between subjective income, religious commitment, and satisfaction toward democracy, as shown in Figure 1. Each of the variables has been chosen based on the findings proposed by the review of the previous literature: Graham and Sukhtankar (2004) found a link between economic well-being and support toward democracy in Latin America; De la Torre (2005) also linked dissatisfaction toward the democratic regime with the prevailing inequality in most Latin American countries; for their part, Bergh and Bjørnskov (2014) found a link between social trust, welfare policies, and the reduction of the economic gap; similarly, Alister et al. (2015) found a relation between personal economy and democratic support; also, Wences and Güemes (2016) observed that inequality helped explain the lack of confidence in Latin American societies.

Regarding the relation between religious commitment and support for democracy, De Roux (2014) described the different political tendencies assumed by the Catholic Church in Latin America, although this author roughly states that this institution considers that religion is a public matter, "a matter of society" (p. 46). Therefore, it is easy to deduce the connection to democracy in a region where about 
nine out of 10 people are attached to some type of religious organization (Pew Research Center 2014, November 13), and where the institution that guards these values assumes a public role that is visible both in the political organizations in which it was merged (De Roux 2014), in the social movements that have been emerging - many of them stimulated by religious figures or centers (Levine 2015) —and even in the transformation of religious practices that, as explained by Parker (2016) and Blancarte (2016), are characteristics of contemporary Latin American societies in the broadest context possible.

\section{Methodology}

The correlational scope study seeks to analyze the interactions between the proposed variables based on the hypothetical model presented in Figure 1. To do this, first, we downloaded the data provided in SPSS by Latinobarómetro (latinobarometro.org) for 2016: this is a non-profit organization, which since 1995 and through different surveys, has been responsible for monitoring public opinion in Latin America. Their data has been used by numerous studies, which have deepened on phenomena similar to this work (Ateca et al. 2014; Ergun et al. 2016; Monsiváis 2017).

Before addressing the description of the results, some preliminary steps were taken to standardize the variables that intervened in the model. In the first place, we are aware that given the religious diversity that exists in Latin America, belonging to one religion or another can modify the results. (Jungblut 2015; Cipriani 2015). However, rather than delving into how individuals of different beliefs respond when supporting democracy, we seek to understand how religious commitment can intervene in the relation between subjective income and satisfaction toward democracy. For this reason, and based on the data of the Latinobarómetro corresponding to 2016, the religious commitment variable was taken from the question "if you consider that [you] belong to a religion". The survey asked respondents to mark their identification with seven possible answers: Extreme Follower; Follower; Causal Follower; Non-Follower; Do Not Know; No Answer; Not Applicable. To prepare the analysis, the answers were recoded into five items of response that fit into a Likert scale: Without Religion; Non-Follower; Causal Follower; Follower; and Extreme Follower. It is important to remark that we did not focus on any concrete religion, but rather on general religious commitment and, in concrete, in the recognized practices and personal experimentation and assimilation of religions. In second place, the variable of subjective income was taken from the question: "How fair do you think is the income distribution of the country?". The possible answers were originally coded in a scale of six items: Very Fair; Fair; Unfair; Very Unfair; Do Not Know; No Answer. Also, the variable of satisfaction toward the functioning of democracy was taken from the question "In general, would you say that you are Satisfied, More or Less Satisfied, Not Satisfied, or Not Satisfied at All with the functioning of the democracy in your country?" This question had two more options: Do not Know; and No Answer. In both variables-subjective income and satisfaction with democracy - two Likert-type scales were created by enabling a neutral section that synthesized the answers Do Not Know and No Answer, which were initially excluded in the matrix provided by the Latinobarómetro.

In total, we analyzed 20,204 surveys from the 18 countries that were included in the survey of Latinobarómetro with the following distribution (presented by the same survey): Argentina $(n=1200)$, Bolivia $(n=1200)$, Brazil $(n=1204)$, Chile $(n=1200)$, Colombia $(n=1200)$, Costa Rica $(n=1000)$, Dominican Republic $(n=1000)$, Ecuador $(n=1200)$, El Salvador $(n=1000)$, Guatemala $(n=1000)$, Honduras $(n=1000)$, Mexico $(n=1200)$, Nicaragua $(n=1000)$, Panama $(n=1000)$, Paraguay $(n=1200)$, Peru $(n=1200)$, Uruguay $(n=1200)$, and Venezuela $(n=1200)$. All of them at present have democratic models, including those such as Venezuela or Mexico, among others, even though some countries have unstable and eroded institutional systems (Mainwaring and Pérez-Liñán 2015), and some other studies have examined the same sample that has been proposed to understand the Latin American situation (Zmerli and Castillo 2015).

To verify the hypotheses, we performed a statistical mediation analysis (Barredo et al. 2015; Hayes 2018), while we seek to detect how religious commitment affects the relation between the independent or preceding variable (subjective income) and the dependent or consequent variable 
(satisfaction toward democracy). This analysis was done through the macro PROCESS version 3.0 (Model 4) for SPSS (version 25), with 10,000 bootstrap replicates and a 95\% confidence level. For the mediation analysis, the sample considered by the software was 20,078 individuals, since the program automatically excludes the lost values.

\section{Results}

\subsection{Preliminary Correlation Analysis}

The results shown below (Table 1) indicate significant relations between the variables that have been taken to build the model that supports this article, among which the inverse relation between religious commitment and subjective income stands out. In other words, those Latin Americans who showed a higher subjective income recognized having a lower religious commitment.

Table 1. Matrix of correlations between the variables that make up the model.

\begin{tabular}{lccc}
\hline & Subjective Income & $\begin{array}{c}\text { Religious } \\
\text { Commitment }\end{array}$ & $\begin{array}{c}\text { Satisfaction toward the } \\
\text { Functioning of Democracy }\end{array}$ \\
\hline $\begin{array}{l}\text { 1-Subjective income } \\
\text { 2-Religious commitment }\end{array}$ & - & $-\mathbf{0 . 3 0 * * *}$ & $0.10^{* * *}$ \\
$\begin{array}{l}\text { 3-Satisfaction toward the } \\
\text { functioning of democracy }\end{array}$ & $0.10^{* * *}$ & - & $-\mathbf{0 . 3 5 * *}$ \\
\hline
\end{tabular}

Source: Latinobarómetro (2016); Note: ${ }^{* * *} p<0.001$.

\subsection{Moderate Mediation Analysis}

Religious organizations-especially Catholicism, as the predominant religion in the Latin American context-managed to take root with rituals, representations, and myths (Mallimaci 2017), to the point that, as this author explains from a theoretical perspective, it is very complicated to separate its influence from the political and cultural. For Levine (2015), these religious organizations have played an important role in Latin America by "promoting democracy in small communities" (p. 174), just due to the opportunities for believers to interact, discuss, and debate the problems related to their collective. From an empirical approach, and in order to contrast the hypotheses, we developed a mediation analysis (Barredo et al. 2015; Hayes 2018) based on regressions. As shown below, we found a direct effect between subjective income and satisfaction toward the functioning of democracy $(B=0.10$, $p<0.001, \mathrm{CI}=0.08$ to 0.11 ); therefore, $\mathrm{H} 1$ checks out.

In this regard, since it is a positive relation, it is possible to predict that to the extent that Latin American respondents recognize the existence of a greater subjective income, there is also a greater satisfaction toward democratic systems in the region. Likewise, after the analysis, we also validate $\mathrm{H} 2$, meaning that there is an indirect effect mediated by religious commitment $(\mathrm{B}=0.001, \mathrm{CI}=0.0004$ to 0.017 ) between subjective income and satisfaction toward the functioning of democracy. In this regard, and to the extent that respondents recognize that they have a higher subjective income and possess a greater religious commitment, they will probably manifest greater satisfaction with the functioning of democracy. Religion, as explained by Levine (1981) in a classic work, is responsible for providing symbolic models that facilitate the understanding of the world, and therefore could help facilitate a greater acceptance of democratic systems such as Latin American ones, which have been characterized by relative instability (Mainwaring and Pérez-Liñán 2015). In fact, these authors only identify Chile, Costa Rica, and Uruguay as stable democracies. However, the indirect effect perceived, which validates the constructed hypothetical model, receives some interesting qualifications with respect to $\mathrm{H} 2.1$ and $\mathrm{H} 2.2$; in this regard, subjective income correlates with religious commitment $(\mathrm{B}=-0.03, p<0.001, \mathrm{CI}=-0.05$ to -0.01$)$, but it is a correlation marked by a negative coefficient. Thus, it is possible to indicate that, to the extent that there is a greater subjective income, we can find in Latin Americans a lower religious commitment, and therefore must discard H2.1. Furthermore, religious 
commitment is correlated with satisfaction toward the functioning of democracy $(\mathrm{B}=-0.02, p<0.001$, $\mathrm{CI}=-0.03$ to -0.01 ), although the negative coefficient makes us discard H2.2, given that with a greater religious commitment, we may verify among Latin Americans a lower satisfaction toward democracy in their countries. Let us remember that through attendance at worship centers-which is an indicator of religious commitment-individuals also receive a constant interference with the political views of priests. Such a tendency was described by the Pew Research Center (2016, August 8) in a study in which the support or the rejection that was projected from the homilies toward some or other candidates in the presidential elections of the USA was verified. Therefore, if an individual denotes a greater religious commitment, he may show greater dissatisfaction with the democratic system in which he lives as a result of aspects such as the alluded interference of priests. Such an individual may also perceive a greater sensitivity toward the environment, among others attitudes. However, it is important to emphasize that once the variables selected in Figure 2 (and not isolated, among them) interact, we find a positive indirect effect between subjective income and satisfaction toward democracy, due to the mediation exercised by religious commitment.

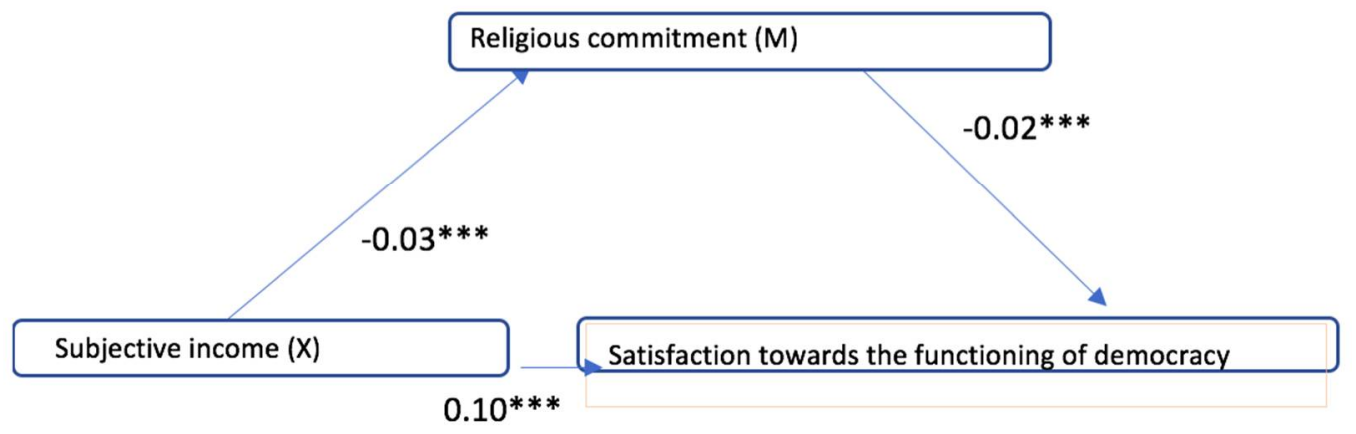

Figure 2. Relation between subjective income and religious commitment toward the functioning of democracy (Y). Note: ${ }^{* * *} p<0.001$. Source: Latinobarómetro (2016); Self-made.

\section{Discussion and Conclusions}

In Latin America, there are very low levels of trust in people and institutions (Wences and Güemes 2016), which is worrisome because it largely hinders the possibilities of democratic participation and, with that, those germs or breaches that can encourage the populism described by Laclau (2006) are formed. As in previous studies, we found a direct link between individual income and satisfaction toward democracy (Graham and Sukhtankar 2004; Alister et al. 2015), because as De la Torre (2005) explained, the exercise of democratic participation is more restricted as the social and economic gaps deepen. In this regard, it is possible to predict that to the extent that individual incomes increase in Latin America, greater satisfaction toward the democratic political system will be consolidated. However, our study contributes to the existing literature on religion and politics, which is very scarce but on the other hand, as highlighted by Iranzo and Manrique (2015), it points to religious commitment as a variable that mediates between subjective income and satisfaction toward democracy. That is, if we verify the correlations between subjective income and satisfaction toward democracy, we find negative coefficients with respect to religious commitment. However, if we follow the recommendations of Hayes (2018) and draw a model of mediation analysis in which the three variables intervene, we observe an indirect positive effect of $X$ (subjective income) over $Y$ (satisfaction with democracy), due to the mediation of the aforementioned religious commitment. Thus, according to the empirical verification of the hypotheses proposed, we conclude that those Latin Americans who perceive a higher level of subjective income and have a greater religious commitment will tend to show greater satisfaction with the functioning of Latin American democracies. This relation is possibly marked by the dual nature of religious centers as legitimators of domination, and as incentives to the demands of the poor (De la Torre and Martín 2016). Likewise, it is also important to note the 
prevalence of a great influence of religious beliefs on Latin Americans. Although since the 20th century, a greater religious plurality has expanded beyond the Catholic Church (Mallimaci 2017; De Roux 2014), still about nine out of 10 Latin Americans recognize themselves as belonging to one religion or another (Pew Research Center 2014, November 13). Therefore, individuals with a greater religious commitment can be more critical toward the environment that surrounds them, especially within the political sphere, which we verify in the relation between religious commitment and satisfaction toward democracy. However, this does not mean that these individuals support an authoritarian form of government. Instead, through their responses, it denotes greater dissatisfaction with contemporary governments. At the same time, perhaps thanks to the participation and discussion that takes place within the bosom of religious organizations (Levine 2015), individuals are more accustomed to finding solutions to the problems raised from dialogue and consensus. In this last conclusion, it is necessary to introduce a nuance: since the 20th century, religious practices are based on great heterogeneity. In this regard, there has been a loss of cult centers as referential environments in the practice of believing, because as Parker (2016) explains, there is an "anti-institutional tendency" in Latin America (p. 24). This tendency also affects politics in general, and according to which the individual search for knowledge determines the construction of personal experience. Blancarte (2016) agreed when perceiving a restructuring of religiosity that was no longer so associated with conventional organizations. From this angle, religious commitment is not only associated with the attendance or not of an individual to a church, for example, but there has been an expansion and integration of religion with other spheres of life. Therefore, the positive indirect effect between religious commitment, subjective income, and satisfaction toward democracy could be explained—as stated by Ateca et al. (2014)—through the constant comparative exercise with the social referential environment. Individuals tend to achieve greater general well-being due to the emotional ties and the emotional reinforcement established in that process. Therefore, religious commitment can be consolidated as that comparative social context that promotes a greater satisfaction toward democracy, insofar as the individual perceives to enjoy higher incomes. In this regard, this study proposes the need to articulate other variables-and not only economic ones-to explain the satisfaction toward democracy. However, these pages have some limitations; the most notorious, which opens a new line of analysis, is the contrast of the influence of each of the Latin American religions with the support toward democracy and its ways of acting, from the different religious affiliations in each national public sphere. Furthermore, it would also be interesting to expand the explanation through the application of qualitative techniques. Since Latinobarómetro only collected data from 18 Latin American countries, the results presented refer to the major Latin American trends, but there are countries that were not included in the original survey-such as Cuba or Surinam, among others-so we were unable to analyze them. At the same time, all of the 18 countries that were represented in the sample present democratic systems, some of them with an authoritarian character. In that sense, it would be nice to analyze each national case more deeply, as there are some contextual variables that have been neutralized in the previous pages. In any case, these are tasks that we relegate for future contributions.

Funding: This research is a product of the project "Public sphere and citizen participation" funded by Big Grants fund of the Universidad del Rosario (Colombia).

Acknowledgments: I would like to thank the valuable comments and the previous reading of Carlos Miguel Rincón (Universidad del Rosario, Colombia) and Carlos Arcila Calderón (University of Salamanca, Spain). The help of Karen Tatiana Pinto Garzón (Universidad del Rosario, Colombia), has also been very valuable.

Conflicts of Interest: The authors declare no conflict of interest. The founding sponsors had no role in the design of the study; in the collection, analyses, or interpretation of data; in the writing of the manuscript, and in the decision to publish the results. 


\section{References}

Alister, Cristian, Constanza Cea, and Alex Guerrero. 2015. Democracia en Latinoamérica, ¿Qué factores influyen en la satisfacción y apoyo a la Democracia? Fronteras 2: 85-113. Available online: http:/ / publicacionescienciassociales. ufro.cl/index.php/fronteras/article/view/445/480 (accessed on 11 March 2018).

Ateca, Victoria, Alexandra Cortés, and Ana Moro. 2014. Social Interactions and Subjective Well-Being: Evidence from Latin America. Journal of Happiness Studies 15: 527-54. [CrossRef]

Barredo, Daniel, Carlos Arcila, Jesús Arroyave, and Roxana Silva. 2015. Influence of Social Networks in the Decision to Vote: An Exploratory Survey on the Ecuadorian Electorate. International Journal of E-Politics 6: 15-34. [CrossRef]

Barredo, Daniel. 2017. Efectos de la imprenta en La Reconquista de Nueva Granada: La republicanización de la opinión pública y la racionalización de la monarquía. Historia y Comunicación Social 22: 415-26. [CrossRef]

Bergh, Aandreas, and Christian Bjørnskov. 2014. Trust, welfare states and income equality: Sorting out the causality. European Journal of Political Economy 35: 183-99. [CrossRef]

Blancarte, Roberto. 2016. En América Latina las instituciones públicas son menos laicas de lo secularizadas que son sus sociedades (entrevista de Juan Cruz Esquivel). Sociedad y Religión: Sociología, Antropología e Historia de la Religión en el Cono Sur XXVI: 130-42. Available online: http: / / www.scielo.org.ar/scielo.php?script=sci_ arttext\&pid=S1853-70812016000100006 (accessed on 14 March 2018).

Cipriani, Roberto. 2015. Religión difusa en América Latina. Sociedad y Religión 44: 269-78. Available online: http:/ / www.scielo.org.ar/pdf/syr/v25n44/v25n44a12.pdf (accessed on 14 March 2018).

De la Torre, Carlos. 2005. Justicia social, democracia y derechos humanos en América Latina. Anuario de Derechos Humanos 6: 673-701. Available online: http:/ / revistas.ucm.es/index.php/ANDH/article/viewFile/ ANDH0505110673A/20870 (accessed on 23 March 2018).

De la Torre, Renée, and Eloisa Martín. 2016. Religious Studies in Latin America. Annual Review of Sociology 42: 473-92. Available online: https:/ / www.annualreviews.org/doi/10.1146/annurev-soc-081715-074427 (accessed on 4 March 2018). [CrossRef]

De Roux, Rodolfo. 2014. La romanización de la Iglesia católica en América Latina: Una estratégia de larga duración. Pro-Posiçôes 25: 31-54. [CrossRef]

Ergun, Selim, Fernanda Rivas, and Máximo Rossi. 2016. Satisfaction with Democracy in Latin America: Do the Characteristics of the Political System Matter? 8, pp. 1-27. Available online: https://works.bepress.com/ maximo_rossi/77/ (accessed on 25 February 2018).

González, Marcos, and Antonio Sánchez. 2006. Libertades fundamentales en las Américas: Devenir de la libertad religiosa en América Latina, los Estados Unidos de América y el sistema interamericano. Revista Jurídica Universidad Autónoma de Madrid 14: 107-25. Available online: https://revistas.uam.es/revistajuridica/ article/view / 6125 (accessed on 14 February 2018).

Graham, Carol, and Sandip Sukhtankar. 2004. Is economic crisis reducing support for markets and democracy in Latin America? Some evidence from surveys of public opinion and well being. Journal of Latin American Studies 36: 349-77. [CrossRef]

Hayes, Andrew. 2018. Introduction to Mediation, Moderation, and Conditional Process Analysis. A Regression-Based Approach, 2nd ed. New York: Guilford Press, ISBN 9781462534654.

Iranzo, Ángela, and Carlos Manrique. 2015. Presentación. Religiones, post-secularidad y democracia en América Latina: Reconguraciones del discurso y la acción política. Revista de Estudios Sociales 51: 9-22. [CrossRef]

Jungblut, Airton. 2015. Ser evangélico en América Latina: Elementos para un análisis. Nueva Sociedad 260: 95-108.

Koenig, Harold H., Bruce Nelson, Sally F. Shaw, Faten Al Zaben, Zhizhong Wang, and Salil Saxena. 2015. Belief into Action Scale: A Brief but Comprehensive Measure of Religious Commitment. Open Journal of Psychiatry 5: 66-77. [CrossRef]

Koole, Sander L., Michael E. McCullough, Julius Kuhl, and Peter Roelofsma. 2010. Why religion's burdens are light: From religiosity to implicit self-regulation. Personality and Social Psychology Review 14: 95-107. [CrossRef] [PubMed]

Laclau, Ernesto. 2006. La deriva populista y la centroizquierda latinoamericana. Nueva Sociedad 205: 56-61. Available online: https:/ / search.proquest.com/openview/7a4af441ba96f895ad49adcb5248a17b/1? pq-origsite $=$ gscholar\&cbl=13322 (accessed on 11 March 2018). 
Latinobarómetro. 2016. Banco de datos-Latinobarómetro 2016. Available online: http:/ /www.latinobarometro. org/latContents.jsp (accessed on 19 February 2018).

Levine, Daniel. 1981. Religion and Politics in Latin America. The Catholic Church in Venezuela E Colombia. Princeton: Princeton University Press, ISBN 9781400854585.

Levine, Daniel. 2015. Violencia y política en América Latina: El lugar de la trama religiosa (entrevista de Marcos Andrés Carbonelli). Sociedad y Religión 43: 169-79. Available online: http:/ /www.scielo.org.ar/pdf/syr/ v25n43/v25n43a07.pdf (accessed on 15 March 2018).

Lipset, Seymour. 1959. Some Social Requisites of Democracy: Economic Development and Political Legitimacy. The American Political Science Review 53: 69-105. [CrossRef]

Mainwaring, Scott, and Aníbal Pérez-Liñán. 2015. La democracia a la deriva en América Latina. PostData 20: 267-94. Available online: http:/ / www.scielo.org.ar/scielo.php?script=sci_arttext\&pid=S185196012015000200001 (accessed on 19 February 2018).

Mallimaci, Fortunato. 2017. Modernidades religiosas latinoamericanas: Un renovado debate epistemológico y conceptual. Caravelle 108: 15-33. [CrossRef]

Mato, Daniel. 2015. Pueblos indígenas, Estados y educación superior: Aprendizajes de experiencias en varios países de América Latina potencialmente útiles a los procesos en marcha en Argentina. Cuadernos de Antropología Social 41: 5-23. Available online: http:/ / www.scielo.org.ar/scielo.php?script=sci_arttext\&pid= S1850-275X2015000100001 (accessed on 17 February 2018).

Monsiváis, Alejandro. 2017. La desafección representativa en América Latina. Andamios 14: 17-41. Available online: http:/ / www.scielo.org.mx/scielo.php?pid=S1870-00632017000300017\&script=sci_arttext\&tlng=pt (accessed on 19 February 2018).

Ortega, Francisco, and Alexander Chaparro. 2012. El nacimiento de la opinión pública en la Nueva Granada, 1785-1830. In Disfraz y pluma de todos. Opinión pública y cultura política, siglos XVIII y XIX. Edited by Ortega Francisco and Alexander Chaparro. Bogotá: Universidad Nacional de Colombia, pp. 37-126. ISBN 978-958-761-195-3.

Parker, Cristian. 2016. Religious Pluralism and New Political Identities in Latin America. Latin American Perspectives 43: 15-30. [CrossRef]

Pew Research Center. 2014. Religion in Latin America. Widespread Change in a Historically Catholic Region. Pew Research Center, November 13. Available online: http:/ / www.pewforum.org/2014/11/13/religion-inlatin-america/ (accessed on 1 April 2018).

Pew Research Center. 2016. Many Americans Hear Politics From the Pulpit. Washington: Pew Research Center, August 8, Available online: http:/ /www.pewforum.org/2016/08/08/many-americans-hear-politics-fromthe-pulpit/ (accessed on 10 April 2018).

Quijano, Anibal. 2011. Colonialidad del poder y subjetividad en America Latina. Contextualizaciones Latinoamericanas 5: 1-13. Available online: http://revistascientificas.udg.mx/index.php/CL/article/view/ $2837 / 2575$ (accessed on 13 March 2018).

Sarrazin, Jean, and Paulina Arango. 2017. La alternativa cristiana en la modernidad tardía. Razones de la migración religiosa del catolicismo al pentecostalismo. Folios 46: 41-54. Available online: http:/ / repositorio. minedu.gob.pe/handle/MINEDU/5417 (accessed on 16 March 2018). [CrossRef]

Verger, Antoni, Mauro Moschetti, and Clara Fontdevila. 2017. La privatización educativa en América Latina: Una cartografía de políticas, tendencias y trayectorias. Barcelona: Internacional de la Educación, Available online: http:/ / repositorio.minedu.gob.pe/handle/MINEDU/5417 (accessed on 20 January 2018).

Wences, Isabel, and Cecilia Güemes. 2016. Democracia republicana y confianza en América Latina: La esperanza que no llega, que no alcanza. Andamios 13: 13-37. Available online: http:/ / www.scielo.org.mx/scielo.php? pid=S1870-00632016000100013\&script=sci_arttext\&tlng=en (accessed on 17 January 2018). [CrossRef]

Zanatta, Loris. 2008. El populismo, entre religión y política. Sobre las raíces históricas del antiliberalismo. Estudios Interdisciplinarios de América Latina y el Caribe 19: 29-44. Available online: http:/ / eial.tau.ac.il/index.php/ eial/article/view/566/529 (accessed on 21 March 2018). 
Zavala, Edgar, and Manuel Góngora. 2016. Secularities, Diversities and Pluralities: Understanding the Challenges of Religious Diversity in Latin America. Social Inclusion 4: 65-76. [CrossRef]

Zmerli, Sonja, and Juan Carlos Castillo. 2015. Income inequality, distributive fairness and political trust in Latin America. Social Science Research 52: 179-92. [CrossRef] [PubMed] 